https://doi.org/10.24101/logos.2020.61

Gauta 20200508

KĘSTUTIS ŽEMAITIS

Vytauto Didžiojo universitetas, Lietuva

Vytautas Magnus University, Lithuania

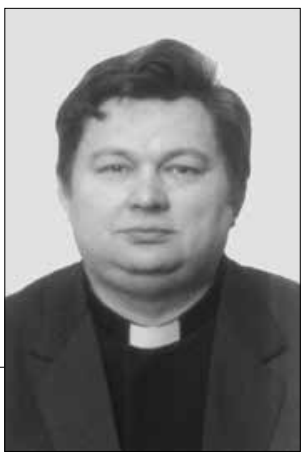

\title{
BIZANTINIAI RITAI: NUO ŠV. JOKŪBO IKI SLAVIŠKOJO DVASINGUMO
}

\author{
Byzantine Rites: From St. James to Slavic Spirituality
}

SUMMARY

The Byzantine liturgy in Eastern Christian Churches has come a long way from the time of apostles to baptized Slavic lands. The texts of the rites and rules of performance were influenced by both theologians and by the character of the faith of baptized peoples who have survived. Although the Byzantine liturgy itself has reached modern times as a whole family of separate and somewhat different rites, there has been a continuous thread from St. James' Jerusalem to Slavic-Russian spirituality.

\section{SANTRAUKA}

Bizantinės liturgijos įvairovė Rytų krikščionių bažnyčiose praejjo ilgą formavimosi kelią nuo pat apaštalų laikų iki pasikrikštijusių slavų. Apeigų tekstams bei liturgijos atlikimo taisyklèms įtakos turèjo ir kai kurie teologai, ir pačiu pakrikštytų tautu tikẻjimo išgyvenimo charakteris. Ir nors pati bizantiškoji liturgija naujuosius laikus pasiekè kaip visa atskirų ir kažkiek skirtingų ritų šeima, tačiau ji nuo šv. Jokūbo Jeruzalèje iki pat slaviško - rusiško dvasingumo tarsi sujungta nepertraukiama gija. Taip krikščionybei plintant i slavų kraštus neabejotinai į tuos kraštus atėjo ir senoji liturginė tradicija. Pati Bizantinè liturgija, siekianti pirmuosius kriǩčionybės amžius, pasižyminti simbolizmu ir iškilmingumu, turi sąsajų su Palestinos, Antiochijos ir Konstantinopolio liturginėmis tradicijomis. Katalikų Bažnyčia ypač vertina Rytų liturginius ritus, kurie susiformavo dar ankstyvaisiais krikščionybès amžiais.

\section{INTRODUCTION}

The first Christian communities did not have a unified liturgical rite. Rites in the East were particularly diverse. More

pronounced differences were seen not only between Alexandria and Antioch, Constantinople and Armenians, but also

RAKTAŽODŽIAI: ritai, bizantinė liturgija, slaviškas dvasingumas.

KEY WORDS: rites, Byzantine liturgy, slavic spirituality. 
in Syria, Egypt and Byzantium. Of course, this does not mean that each community had its own rules, but larger centres became the reasons for unification of the diversity that emerged around it. Why was the East more diverse? In the East, Christians differed more from each other in cultural and ethnic peculiarities, so the tendency of greater diversity was noticed even in the first centuries. In this work, it is important to find out what circumstances influenced the diversity of Byzantine rites, which later dispersed considerably, on the way from the spirituality of St. James to Slavic and perhaps even more Russian spirituality. This work is also relevant in that little has been written about this topic in Lithuania.

\section{CIRCUMSTANCES OF THE FORMATION OF BYZANTINE LITURGICAL RITE}

In the Eastern Church we can find a variety of rites in the early days of Christianity. Already in Didache we see a beginning where highly respected teachers and prophets are allowed to speak a prayer of thanksgiving in their own words (Didache X.7). It should be emphasized that even today the Catholic Church respects "spiritual qualities and talents" of nations if it is compatible "with the requirements of a true liturgical spirit" (Sacrosanctrumconsilium, XXXVII). Thus, a possible departure from the existing strict rules is acknowledged here. However, the second century saw such small liturgical things grow into greater disagreements. The first of such serious liturgical controversies in the Church arose over the date of the celebration of Easter. In the biography of Bishop Polycarp of Smyrna we find a discussion on this issue between him and Pope Anicetus. While this did not harm the unity of the Church, it showed a maturing diversity. St. Jerome also testifies to how he, in his journey to the Holy Land, was obliged to conform to liturgical customs of various communities. Later, these liturgical differences united around larger ecclesiastical centres in the East.

It must be acknowledged that liturgical customs were influenced by cultural differences in the East: Antioch, Alexandria, Jerusalem. It is where religious centres were formed. The emerging rites were also influenced by the monastic movement, especially the Desert Fathers. The desert environment helped the hermits survive theology. Their lives were marked by contemplation. In this way theology acquired an even greater mystical character. Thus, according to Wlodzimierz Łosski, there was a close connection between theology and mysticism (Łosski 1898: 6). And this influenced the character of the liturgy. The fourth-century Bishop Cyril of Jerusalem, speaking in his catechesis on the sacraments of Christianity, speaks of them as simply mysteries of the liturgy (S. Cyrillus Herosolymitanus, Catecheses, (myst.) 2). Paul Evdokimov, a theologian of the Eastern Church, states that contempla- 
tion also helps to know God (Evdokimov 1996: 54). And the first to know Him best were anachorites. "The desert is a positive and beautiful place where those who desire it can meet God, hear Him and live with Him. The renunciation also meant that fathers and mothers of the desert became unnoticeable, resembling the desert sand" (Chryssavgis 2011: 112). This is where the essence of the desert comes into play: "And renunciation encourages union with the environment. Their holiness was part of the sense of the whole. To become one with one's neighbour is the essence of the spirituality of the desert, it also means to be in harmony with the environment, the world, with God" (ibid., P.113), writes John Chryssavgis, a researcher of monasticism. This experience could not fail to influence liturgical traditions.

However, when considering this issue, it is first necessary to assess the contributions of specific individuals to the formation of Eastern Liturgy. The liturgical separation between the Synagogue and the Church did not pass without the Anti-Echoic tradition called St. The Liturgy of James. Later, Basil the Great (329-379), who lived in Cappadocia, had a great influence. The anaphors he created $^{1}$ became central to the Greco-Slavic churches. Important for the Byzantine liturgy are John Chrysostom (345-407) and John of Damascus (c. 676-749). Thus, under the influence of Christian theology, Greek culture, language, Syrian liturgical customs, and the tradition of celebrating the Cappadocian Eucharist, the Byzantine rite also formed. This rite could not have been influenced by the solemnity and splendour favoured in the emperor's environment. Therefore, the Divine Liturgy is performed here exclusively (Мень 1991: 31-50). John Chrysostom's liturgy is especially common in the East. It is close to the family of liturgical rites in Syria, that is, the Alexander Rites of Egypt. Here you can feel the influence of St. Mark and St. James. They all influenced the Byzantine rites.

As for the Byzantine liturgical rites, it is necessary to look at the general diversity of rites in the East. So, as the roots of the Byzantine Tradition lie in the foundations of the Syrian and Alexandrian liturgy. Mauricio Gordillo compiled a scheme of liturgical rites for Eastern Christians, which reflects their spread in individual communities that roughly coincide with the Eastern Patriarchates. As already mentioned, Alexander and Antioch's Liturgy more or less influenced the Byzantine liturgy and very similar Armenian liturgy. As for the beginning of liturgical rites, we notice some of its features in early Christianity. The role of a deacon is highlighted in the liturgy of J St. James. ${ }^{2}$ Music plays a very important role (Мень 1991:23).

In Byzantine Eucharistic rites, St. Basil the Great ${ }^{3}$ and St. John Chrysostom ${ }^{4}$ texts differ from each other by an anaphor and several other prayers. There are no significant differences in other rites as well. 


\section{LITURGICAL RITES BELONGING TO THE BYZANTINE CHURCHES ${ }^{5}$}

Byzantine rite:

1-Greek Byzantine rite.

2-Melkites Byzantine rite.

3-Slavic Byzantine rite:

a) the old Russian rite

b) reformed Russian rite

c) Bulgarian rite

d) Ukrainian (Ruthenian).

4-RomanianByzantine rite

5-ItalianByzantine rite:

a) Kriptoferat rite

b) Italian Albanian rite

6-GeorgianByzantine rite

7-RomanByzantine rite

In addition to the above-mentioned factors that determined the peculiarities of the rites, Romano Guardini rightly observes that "... the forms of the liturgy have been constantly polished, decorated and combined for many centuries" (Guardini 2015: 45).These rites were also influenced by specific events, such as Patriarch Nikon's liturgical reform in Russia $^{6}$. Later, after the union of Brasta, the process of Latinization of Ruthenian rites took place (Kajack 1982: 52). Thus, the family of the Byzantine rites was constantly changing and growing. Even the original Greek language quickly gave way to others when liturgical books were translated into local languages especially after Slavic baptism. Only the Melchites, praying in Syriac, later accepted Arabic.

\section{SLAVIC INFLUENCE ON BYZANTINE RITES}

With the spread of Christianity to the Slavic lands, the liturgical tradition undoubtedly entered those lands as well. Of course, the newly baptized nations also adopted the liturgical traditions of Constantinople. Yet those traditions were influenced by both local customs and languages. The Eastern liturgy, in pursuit of the ancient ages, can function as a school of believers that cultivates a "Christian taste," (Špidlik 207: 298) where "spiritual beauty connects with the beauty of this world" (Bulgakov 2006: 201). For this, T. Špidlik warns that such greatness may become formalism and contradict the simplicity of prayer (Špidlik 207: 298).

The Slavs gave the Byzantine rites the same mystical character as they had in the early Church in the East. This is very clearly reflected in the sacraments of Christianization. In the Byzantine Tradition, the theology and liturgy of the sacraments of Christianization go back to the relatively old generations of the Eastern Church, as evidenced by the teachings of Cyril of Jerusalem. So, we see that its various rites (not only of Antioch, but also of Jerusalem) seem to be intertwined in ancient times and are reflected in the Byzantine Church, as well as in the Slavic lands. The services are performed here in their own language. This does not diminish their mystical character. Metropolitan Filaret says that "Baptism is the sacrament during which the baptized person is immersed three times in water in the name of the Father, the Son and the Holy Spirit, dies to a "carnal" sinful life and is born into a new - spiritual 
and holy life" (Филареть 1997: 70). At the end of the baptismal liturgy, the body of the baptized believer is anointed with holy oil in the name of the Holy Spirit. Therefore, the person also receives the sacrament of confirmation here. Therefore, as is claimed by Metropolitan Filaret, through this sacrament the person receives gifts of the Holy Spirit, leading him to a firm spiritual life (ibid., P. 73). Sergei Bulgakov writes: "The Eucharist is the tasting of heavenly bread, receiving a part of the Body and Blood of Christ according to the commandments of Christ himself" (Bulgakov 2006: 181).

In the middle of the Byzantine period, art became increasingly liturgical in nature. With the decline of the Byzantine Empire, Byzantine art outside the empire became less and less influential. The character of Russian Orthodox spirituality was also influenced by ecclesiastical art. Byzantine art was able to influence even the western world. Byzantine art had an equally strong influence on Slavic lands. The Slavic lands developed their own style, although they never forgot Byzantine roots (Weitzman 1999: 309). The liturgy of the Slavs, as well as the Russian Orthodox, is also influenced by church music (Wołosiuk 1999: 371372), therefore Canon plays a significant role in the ceremonies.

The Byzantine liturgy as a branch of liturgical science began to develop rapidly as early as the 19th century. By the twentieth century, it was already being developed not only in Russia. Among the famous Orthodox theologians, we see Sergei Bulgakov (1871-1944) - a Russian Orthodox theologian and philoso- pher, S. Bulgakov observes that in the rites "spiritual beauty intertwines with the beauty of this world. With regard to the Russian liturgy, it is worth mentioning that a new wave of Russian artistic talent has entered this sacred Byzantine heritage, making the Russian Church a continuation of Byzantium" (Bulgakov 2006: 201-202). Alexander Мень, however, warns that this ornate liturgy must first retain the character of the Sacrifice (Мень1991: 32). This liturgy clearly acquires a Christocentric character.

The Orthodox liturgy was greatly influenced by Mariology. This was mentioned by many experts of Orthodox Mariology. ${ }^{7}$ Mariology strongly associates Orthodox spirituality with the teaching of the Catholic Church:

In the liturgical cult, Mary, the eternal Virgin, solemnly proclaimed the Most Holy Mother of God by the General Council of Ephesus, in order for Christ, according to the Scriptures, to be truly and literally recognized as the Son of God and the Son of Man, is exalted in the East by the most beautiful hymns; similarly revered by many saints, including the Fathers of the universal Church (Unitatis redintegratio 15).

But Russian spirituality is still felt in the liturgy. The texts found in it (as evidenced by ancient Russian sources) date back to the 11th century. They show a lot of respect for the Kievan Rus'Baptist Grand Prince Vladimir the Great (Дебедь 2019: 372). And, in general, ancient sources testify to the great contribution by the Slavs, specifically the Russians, to the Byzantine liturgy - to texts, and especially to hymns (ibid., Pp. 369-373). 
Modern Russian theologian and philosopher Sergei Bulgakov seems to summarize the essential features of the Orthodox liturgy:

Such is the essential sense of orthodoxy, directly reflected in its rites. All of them testify to and implement such a concept of life, a true experience of the incarnation of God culminating in the resurrection. Because of this sense, Orthodoxy certainly has the experience of early Christianity and its joy (Bulgakov 2006: 181).

The Catholic Church sees many wonderful things that the Orthodox have preserved in their Byzantine rites to which they also added their spirituality:
It is also well known with what love Eastern Christians perform the liturgical rites, especially the celebration of the Eucharist, the source of the Church's life, and the celebration of future glory. Through the former, believers united with the bishop and endowed with the Holy Spirit are opened the way to the Father through the Son, the incarnate. In this way they come into communion with the Blessed Trinity and become "partakers of the divine nature" (2 Pt 1: 4). Thus, by the celebration of the Lord's Eucharist, the Church of God is built and grown in these particular Churches, and by concelebration, the communion between them is expressed (Unitatisredintegratio 15).

\section{CONCLUSIONS}

Already in the first centuries of Christianity, liturgical differences were observed in some individual subChurches. Those differences were tolerated because essentials were maintained everywhere. Later, liturgical rites unified around larger centres. The Catholic Church especially values Eastern liturgical rites that were formed in the early centuries of Christianity. These rites are

\section{References}

Bulgakovas Sergejus. 2006. Stačiatikybe. Vilnius: kataliku pasaulio leidiniai.

Chryssavis. 2011. Dykumos širdyje. Dykumos tèvų ir motinu dvasingumas. Vilnius.

Didache X.7

Divinas Missa Sanctilacobi Apostoli et fratris Domini, p. 16/ Liturgiae, Sive Missaesanctorum Patrum: Iacobi Apostoli et fratris Domini: Basilij Madni, e vetustocodicce Latinae tradicionis: Ioannis Chrisostomi, Interprete Leone Thusico.

Evdokimov Pavel. 1996. Poznanie Boga w Kościele Wschodnim. Kraków. also often used by Christians who have formed a union with the Roman Catholic Church.

The Byzantine liturgy itself, which dates back to the first centuries of Christianity and is characterized by symbolism and solemnity "seen" from the imperial manor of Constantinople, is the result of Palestinian and Constantinople traditions.

Guardini Romano. 2015. Apie liturgijos dvasia. Vilnius: kataliku pasaulio leidiniai.

Kajackas Algimantas. 1982. Rytų ir vakarų Bažnyčių unija Lietuvos-Lenkijos valstybèje 1414-1772 metais (rankraštis, K. Žemaičio asmeninis archyvas), Kaunas.

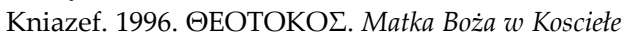
pravostawnym. Warszawa.

S.Cyrillus Herosolymitanus, Catecheses.

Sacrosanctrumc onsilium, XXXVII/ Konstitucija apie Šventaja liturgija. Vatikano II susirinkimo dokumentai. 
Špidlik. 2007. Krikščioniškuju Rytu dvasingumas. Vilnius.

Unitatis redintegratio 15/ Dekretas dèl ekumenizmo. Vatikano II susirinkimo dokumentai.

Weitzman. 1999. Pochodzienie i znaczienieikon/ Prawosławie. Światto wiary i zdrój doświadczenia. Lublin.

Łosski. 1989. Teologia mistyczna Kosciola Wschodniego. Warszawa.

Wołosiuk. 1999. Bizantynska muzyka cerkewna/ Prawosławie. Swiatto wiary i zdrój doświadczenia. Lublin.

\section{Endnotes}

${ }^{1}$ Anaphora ( $\dot{\alpha} v \alpha \phi o 0 \alpha \dot{\alpha}$ - in ancient Greek - the ascension) is the most important part of the Eucharistic liturgy, corresponding in the Catholic liturgy to Eucharistic Prayer of St. Mass.

2 Divinas Missa Sancti Iacobi Apostoli et fratris Domini, p. 16 / Liturgiae, Sive Missae sanctorum Patrum: Iacobi Apostoli et fratris Domini: Basilij Madni, e vetus toco dice Latin aetradicionis: Ioannis Chrisostomi, Interprete Leone Thusico.

${ }^{3}$ On the eve of Christmas and the baptism of Christ, St. Basil's Day, the first 5 Lenten Sundays, Good Thursday and Good Saturday)

${ }^{4}$ Used on all days of the year except when using the great liturgy of Basil.
Мень. 1991. Православное богослужение, таинство, слово и образ. Москва.

Филареть. 1997. Пространный хрисіанскій катіхизись. Владимир.

Издание храма Святителя Николая в Хамовниках. 1992. О Таинстве Крещения, Красноармейск.

Провославное Богослужение, Переводы Богослужебных книг, Year, city and page not specified.

Пебедь. 2019.Богослужебние тексты русского происхождения. Введение в историю Церкви, часть 3. Санкт-Петербург.

5 The table of liturgical rites is prepared according to Gardillo Mauricius S.J., Compendium Theologiae Orientalis, Ramae 1950, p. 18.

${ }^{6}$ During the ecclesiastical reform carried out by Patriarch Nikon of the Orthodox Church in Russia in 1653, mistakes in liturgical texts were corrected, prayer books were harmonized with Orthodox Greek texts, 3-fingered praying was introduced, polyphonic chanting, preaching, and other liturgical elements were specified.

7 Alexis Kniazeff, Matka Boža w Koscielie pravoslavnym, Warszawa 1996. Kniazef A., @EOTO-

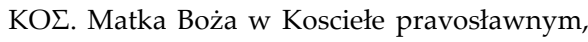
Warszawa 1996. 